\title{
AKSIOLOGI ILMU MANAJEMEN PENDIDIKAN ISLAM UNIVERSITAS ISLAM NEGERI WALISONGO SEMARANG
}

\author{
Danusiri \\ Universitas Islam Negeri Walisongo, Semarang, Indonesia \\ danusiri@walisongo.ac.id
}

\begin{abstract}
Unity of science project is assumed to have useful values. The basis for the assumption refers to the Qur'an Surrah Ali Imran: 191 that all creations have benefits. Empirically, it can be seen that waste can be recycled and bring benefits. This paper explores the axiological value of Islamic education management.

The axiological route of Islamic education management departs from the reality that knowledge is certain. The development of knowledge is based on revelation. By using a philosophical way of thinking, the axiology of Islamic education management is derived from Islamic education. The science of Islamic education is derived from Islamic science. Islamic knowledge is derived from the interpretation of the Qur'an and asSunnah which are believed to be derived from the word of Allah.

On the other hand, Islamic management science is the development of management science. Management science is derived from economics. Economics is derived from sociology. Sociology is derived from anthropology. Anthropology is derived from philosophy. So the science of Islamic education management has two ancestors, namely revelation and philosophy. The unification of the two sources is done by formulating the idea of a unity of science. The missionary direction of unity of science applies to every branch of madhhab of UIN Walisongo Semarang, including Islamic Education management science which has a subbranch of axiology of Islamic Education management science. In this way, regardless of the type of study program at UIN Walisongo, it should reflect broad, deep, organizational scientific insight from revelation to empirical reality, and contains both theoretical and practical benefits.
\end{abstract}

Keywords: revelation, philosophy, scientific development, benefits of Islamic education management 


\section{ABSTRAK}

Proyek ilmiah Unity of science diasumsikan memiliki nilai manfaat. Dasar asumsinya mengacu surat Ali Imran: 191 bahwa segala ciptaan ada manfaatnya. Secara empirik dapat disaksikan bahwa sampah ternyata dapat didaur ulang dan mendatangkan manfaat. Tulisan ini mengetengahkan nilai aksiologi manajemen Pendidikan Islam.

Rute aksiologi manajemen Pendidikan Islam bertolak dari realitas bahwa ilmu adalah niscaya. Pengembangan ilmu didasarkan pada wahyu. Dengan menggunakan cara berpikir kefilsafatan, aksiologi ilmu manajemen Pendidikan Islam diturunkan dari ilmu Pendidikan Islam. Ilmu Pendidikan Islam diturunkan dari ilmu Islam. Ilmu Islam diturunkan dari tafsir Alquran dan as-sunnah yang secara imaniah bersumber dari kalamullah.

Di sisi lain, ilmu manajemen Islam merupakan pengembangan ilmu manajemen. Ilmu manajemen diturunkan dari ilmu ekonomi. Ilmu ekonomi diturunkan dari sosiologi. Sosiologi diturunkan dari antropologi. Antropologi diturunkan dari filsafat. Jadi ilmu manajemen Pendidikan Islam memiliki dua moyang, yaitu wahyu dan filsafat. Penyatuan dua sumber dilakukan dengan memformulasikan gagasan tentang unity of science. Arah misionaris unity of science berlaku pada setiap cabang ilmu madzhab UIN Walisongo Semarang, termasuk ilmu manajemen Pendidikan Islam yang memiliki sub cabang aksiologi ilmu manajemen Pendidikan Islam. Dengan cara ini, apapun jenis program studi di lingkungan UIN Walisongo mencerminkan wawasan keilmuan yang luas, mendalam, organistik sejak dari wahyu hingga kenyataan empiris, dan terkandung nilai manfaat teoritis maupun praktis.

Kata Kunci: Wahyu, Filsafat, Pengembangan Ilmu, Nilai Manajemen Pendidikan Islam

\section{PENDAHULUAN}

Keberadaan (ontologi) Program Studi Manajemen Pendidikan Islam itu nyata. Kualitas kenyataannya bersifat empiris dan legal. Program studi ini menjadi bagian (juziyyah) dari FITK (Fakultas Ilmu Tarbiyah dan Keguruan). FITK menjadi bagian (juziyyah) dari UIN Walisongo Semarang. Legalitasnya antara lain berdasar Peraturan Menteri Agama tahun 2010 tentang perubahan prodi pemikiran Pendidikan Islam di lingkungan Perguruan Tinggi Agama Islam menjadi Program Studi Manajemen Pendidikan Islam. Melalui Peraturan Mentri Agama (PMA) inilah program studi MPI seluruh Indonesia menjadi legal sehingga bisa beroperasi sebagai Lembaga Pendidikan agama Islam tingkat tinggi, 
termasuk MPI (Manajemen Pendidikan Islam) di FITK UIN Walisongo Semarang.

Formalitas keberadaan keilmuan MPI belum sepenuhnya didasarkan pada ontologi maupun epistemologi kefilsafatan Islam. Sementara itu, sejarah manajemen sejak peradaban Mesopotamia hingga manajemen mutakhir ini, tidak berbasis keagamaan ${ }^{1}$. Di sisi lain, bangunan unity of science yang dikembangkan oleh madzhab UIN Walisongo dengan menjadikan wahyu sebagai dasar keilmuan belum tampak sosok organismenya dengan filsafat manajemen pendidikan Islam, baik ontologi, epistemologi, maupun aksiologinya. Sejauh ini, seluruh ilmu keislaman dalam seluruh program studi di lingkungan UIN Walisongo hanyalah matakuliah filsafat kesatuan ilmu yang hanya berbobot dua SKS. Dalam kesempatan ini, penulis hendak mengetengahkan gagasan tentang sosok aksiologi filsafat manejemen pendidikan Islam sebagai bagian dari filsafat kesatuan ilmu, sebagai sub ilmu filsafat manajemen Pendidikan Islam.

\section{Temuan}

Secara historis, filsafat manajemen Pendidikan Islam merupakan pengembangan lebih lanjut dari filsafat manajemen Pendidikan yang bebas dari ikatan wahyu dalam semua langkah kefilsafatannya. Filsafat manajemen Pendidikan didevinsikan sebagai upaya pengelolaan seluruh aktifitas untuk mengetahui hakikat keberadaan Pendidikan dalam kehidupan masyarakat dan mencari jawaban epistemologi seluruh sumber pengetahuan dan teori yang terkait dengan manajemen. Ending pencarian filosofis akan ditemukan baik tujuan maupun nilai manfaat manajemen Pendidikan, yakni pengembangan seluruh sitem yang terkait secara integral dalam dunia Pendidikan ${ }^{2}$. Melalui devinisi ini dapat dikembangkan dengan memunculkan cabang ilmu baru, yaitu filsafat menejemen Pendidikan Islam. Asumsi yang mendasari pengembangan ini adalah ajaran Alquran bahwa Islam itu menjelaskan segala sesuatu (QS an-Naḥl16:89). Sinergi dengan pernyataan ini adalah pernyataan bahwa tidak ada sesuatupun di alam semesta ini yang dialpakan (QS al$A n^{\prime}$ am/6:38) sebagai perwujudan Islam rahmatan lil 'alamin (QS al-

\footnotetext{
${ }^{1}$ Saefullah, Manajemen Pendidikan Islam (Bandung: Pustaka Setia, 2019).

2 Ahmad Beni Saebani dan Koko Komarudin, Filsafat Manajemen Pendidikan (Bandung: Pustaka Setia, 2016).
} 
Anbiyâ'/21:107). Cabang ilmu baru ini dibangun dengan cara menyertakan campur tangan wahyu: Alquran, as-sunnah, dan ijtihat para ulama sejak muasal ilmu hingga muaranya. Hasil akhir kegiatan pengembngan ilmu ini akan dapat dikenali secara jelas sosoknya (the body of science) bahwa filsafat manajemen Pendidikan berbeda dari filsafat manajemen Pendidikan Islam. Pengembangan lebih lanjut mengarah pada cabangnya yang lebih mikro, yaitu epistemologi manajemen Pendidikan Islam dan aksiologi manajemen Pendidikan Islam. Dengan demikian, sosok aksiologi manajemen Pendidikan Islam memiliki dua basis kefilsafatan, yaitu filsafat Pendidikan Islam dan filsafat kesatuan ilmu. Secara praktis filsafat kesatuan ilmu dinamakan juga waḥdatul 'ulūm atau unity ofscinece.

\section{A. Dari Asumsi Menuju Iman}

Dalam tradisi Barat yang sekularistik, berfilsafat selalu bertolak dari asumsi. Berbeda dari cara pandang Barat, apapun yang berkaitan dengan Islam, termasuk menggagas tentang aksiologi Islam, selalu berangkat dari iman. Asumsi sering disinonimkan dengan aksioma atau postulat, yaitu pernyataan dalam bentuk pengandaian yang menggiring untuk dibuktikan ${ }^{3}$. Dengan bahasa lain dan semakna, pengertian asumsi adalah suatu anggapan atau dugaan sementara yang dinyatakan dalam bentuk proposisi yang belum dapat dibuktikan kebenarannya serta membutuhkan pembuktian secara langsung. Dalam pengertian lebih praktis, asumsi mengandung makna dugaan yang selanjutnya dianalisis untuk meperoleh jawaban dari dugaan itu ${ }^{4}$.

Dari batasan tentang asumsi seperti itu, dengan melihat kejadian di sekitar kehidupan, bahwa apa yang disebut sampah, ternyata belakangan dapat dimanfaatkan oleh manusia modern. Kotoran kambing, kotoran manusia, kotoran sapi, ternyata dapat dimanfaatkan menjadi bio gas dan tenaga listrik. Tempurung kelapa, yang semula hanya menjadi kayu bakar, belakangan dapat dibuat menjadi souvenir yang memiliki nilai tambah. Air kotor atau air limbah, ternyata dapat didaur ulang dan menjadi air yang siap digunakan sebagai kebutuhan dasar manusia. Barang-barang bekas, ternyata dapat diubah menjadi barang-barang 1976).

${ }^{3}$ De Dagobert Runes, Dictionary of Philosophy (New Jersey: Littlefield Adams Co,

${ }^{4}$ Hamdani, Filsafat Sains (Bandung: Pustaka Setia, 2011). 
berharga dan bernilai ekonomis di tangan para pera perajin dan kreator. Kulit padi (brambut dalam bahasa Jawa) dapat dijadikan bahan bakar atau campuran bahan dasar pembuatan batu bata dan bahan bakar dalam produksi batubata merah. Aneka akar-akaran, dedaunan, dan biji-bijian yang semula tidak bernilai guna, belakangan diubah menjadi obat herbal yang berguna bagi kesehatan manusia atau minimal dianggap berguna karena manusia ingin keburu sehat atau imun dari pandemi covid 19, sementara obat tersebut belum memenuhi uji ilmiah maupun uji klinis yang memadai. Bisa racun ular yang mematikan, ternyata dapat diubah menjadi obat bagi kesehatan manusia ${ }^{5}$. Kiranya semakin hari akan ada saja penemuan-penemuan baru yang semula tidak berguna dan hanya sebagai polusi, belakangan kemudian sangat bermanfaat bagi manusia. Dari sederetan pernyataan ini dapat diasumsikan secara jauh lebih luas bahwa selagi manusia bisa berpikir kreatif, akan senantiasa dapat menemukan manfaat sesuatu yang semula tidak berguna.

Jauh sebelum asumsi ini dirumuskan, sebenarnya terdapat ayat Alquran yang mengandung petunjuk tentang ketidaksia-siaan segala sesuatu. Allah berfirman:

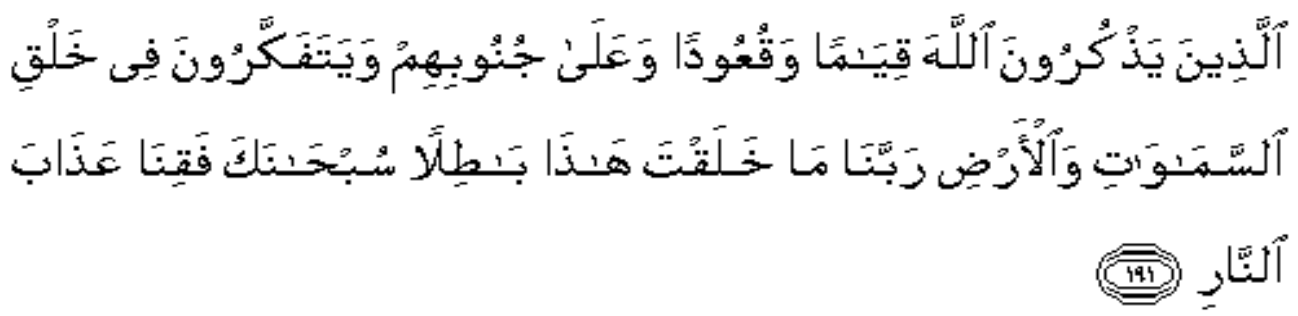

Artinya:

(yaitu) orang-orang yang mengingat Allah sambil berdiri atau duduk atau dalam keadan berbaring dan mereka memikirkan tentang penciptaan langit dan bumi (seraya berkata): "Ya Tuhan kami, tiadalah Engkau menciptakan ini dengan sia-sia, Maha Suci Engkau, maka peliharalah kami dari siksa neraka" (QS Ali Imran/3:191).

Salah satu kandungan pokok ayat ini adalah apapun yang ada di langit-langit dan bumi ada manfaatnya. Kalau ada sesuatu yang tampaknya sia-sia, sebenarnya hanya belum bisa memanfaatkannya.

5 Agus Sumedi, "Peranan Plasmafaresis pada Keracunan Bisa Ular Type Neurotoksik: Studi Kasus di RSCM Jakarta," Penelitian Keperawatan Medik 1, no. 1 (2018): 41-51. 
Karena pernyataan ini berasal dari ayat Alquran yang didibenarkan atas dasar iman, maka pernyataan ini juga mengandung kebenaran imaniah. Segera dapat dinyatakan bahwa asumsi tentang apa saja ada manfaatnya diubah menjadi rumusan iman bahwa seluruh ciptaan Allah bermanfaat bagi kehidupan manusia, atau dengan kata lain "bahwa segala sesuatu ada manfaatnya". Inilah yang dimaksud mensublim asumsi menjadi iman.

Dari pernyataan generalis bahwa semua ciptaan Allah ada manfaatnya mengandung pengertian "manakala seseorang 'membuang sesuatu' karena dirasa tidak ada manfaatnya adalah salah belaka karena menyia-nyiakan pernyataan Allah bahwa segala sesuatu pasti ada manfaatnya. Oleh karena itu, kalau terpaksa seorang muslim-mukmin secara empirik membuang sesuatu harus ada argument teologis dan rasional bahwa ia tidak mebuang sesuatu. Membuang limbah plastik, nasi basi, atau kororan lain harus dikemas bukan membuang sembarangan, melainkan, umpama sedekah kepada makhluk Allah yang habitatnya memang hidup dalam "buangan manusia'. Salah satu rumusan yang dapat dicontohkan di sini, ketika membuang nasi basi di tempat yang tidak membuat polusi di kehidupan manusia adalah sebagai berikut: Ya Allah, aku tidak berniat membuang nasi basi ini, melainkan aku sedekahkan kepada makhluk-Mu yang habitatnya adalah mengonsumsi nasi basi ini dengan cara yang aku tidak tahu. Jika perbuatanku ini salah, aku memohon ampunan kepada-Mu.

\section{B. Problem Aksiologis}

Ketika sudah menyatakan bahwa segala sesuatu ada manfaatnya, dalam dunia ilmu terdapat problem tentang manfaat itu sendiri. Mengenai aspek nilai dalam suatu ilmu terdapat dua golongan besar, satu sama lain saling bertentangan. Kedua paham itu adalah paham ilmu untuk ilmu (the science for the science) dan ilmu untuk yang lain (the science for the others). Senafas dengan paham nilai seni, yaitu the art for the art dan the art for the others ${ }^{6}$.

a. Paradigma ilmu bebas nilai

Ilmu bebas nilai dalam bahasa Inggris sering disebut dengan value free, menyatakan bahwa ilmu dan teknologi adalah bersifat otonom.

\footnotetext{
${ }^{6}$ MM Syarif, Iqbal Tentang Tuhan dan Keindahan (Bandung: Mizan, 1984).
} 
Ilmu secara otonom tidak memiliki keterkaitan sama sekali dengan nilai. Bebas nilai berarti semua kegiatan terkait dengan penyelidikan ilmiah harus disandarkan pada hakikat ilmu itu sendiri. Ilmu menolak campur tangan faktor eksternal yang tidak secara hakiki menentukan ilmu itu sendiri. Josep Situmorang menyatakan ada tiga faktor sebagai indikator bahwa ilmu itu bebas nilai, yaitu:

1). Ilmu harus bebas dari pengendalian-pengendalian nilai. Maksudnya adalah bahwa ilmu harus bebas dari pengaruh eksternal seperti faktor ideologis, religius, kultural, mapun sosial.

2). Diperlukan suasana bebas usaha ilmiah agar otonomi ilmu terjamin. Kebebasan di sini menyangkut kemungkinan yang tersedia dan penentuan diri.

3). Penelitian ilmiah tidak luput dari pertimbangan etis yang sering dituding menghambat kemajuan ilmu, karena nilai etis sendiri itu bersifat universal.

Demi objektifitas ilmiah, maka ilmu harus bebas nilai di luar ilmu itu sendiri. Inilah doktrin yang mereka ajukan ${ }^{7}$. Jadi, nilai ilmu adalah untuk ilmu itu sendiri, the science for the scince.

b. Ilmu untuk yang lain

Manfaat ilmu untuk yang lain di luar ilmu sama dengan ilmu terikat dengan nilai. Ikatan nilai di luar ilmu berada dalam semua langkah ilmu, sejak dari asumsi atau postulat, paradigma, konseptualisasi, teorisasi, saintifikasi, hingga teknologisasi, bahkan sampai aspek teknik, untuk rumpun ilmu-ilmu teknik.

Ketika seorang muslim hendak memulai aktifitas keilmuannya, sebut saja membaca, etika yang menyertainya adalah harus atas nama Allah. Inilah antara lain yang dimaksud ayat "iqra' wa Rabbukal Akram." Sinergi dengan ayat ini adalah hadis Nabi menyatakan bahwa apa saja yang mengandung nilai kebaikan harus dimulai dengan basmalah, yakni menyebut nama Allah, alias perbuatan itu bukan semata-mata atas dasar kemauan pribadi, melainkan justru fondasinya adalah atas nama Allah. Demikian sabda Rasulullah saw:

\footnotetext{
${ }^{7}$ Hamdani, Filsafat Sains.
} 


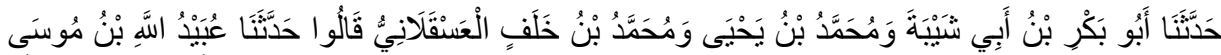

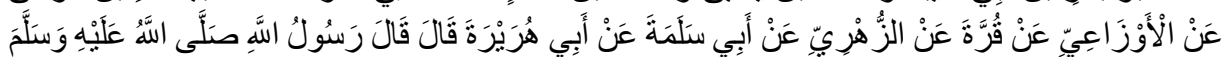

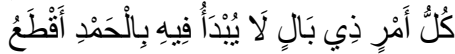

Artinya:

Telah menceritakan kepada kami Abu Bakr bin Abu Syaibah dan Muhammad bin Yahya serta Muhammad bin Khalaf al-'Asqalani mereka berkata; telah menceritakan kepada kami Ubaidullah bin Musa dari al-Auza'i dari Qurrah dari az-Zuhri dari Abu Salamah dari Abu Hurairah ia berkata, "Rasulullah shallallahu 'alaihi wasallam bersabda: "Semua perkara penting yang tidak dimulai dengan h.amdalah adalah sia-sia (HR.Ibnu Majah, 1884).

Dalam hadis lain diungkapkan demikian:

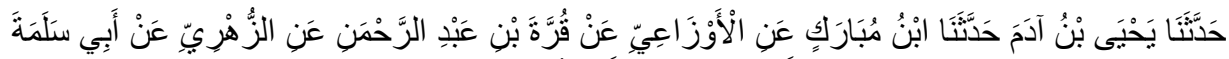

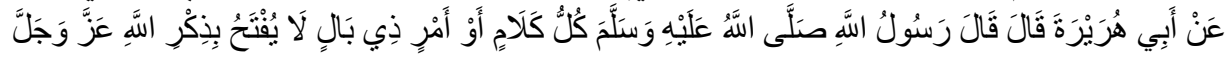

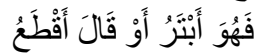

Artinya:

Telah menceritakan kepada kami Yahya bin Adam telah menceritakan kepada kami Ibnu Mubarak dari al-Auza'i dari Qurrah bin Abdurrahman dari az-Zuhri dari Abu Salamah dari Abu Hurairah, dia berkata; Rasulullah shallallahu 'alaihi wasallam bersabda: "Setiap perkataan atau urusan yang yang tidak dibuka dengan zikir kepada Allah maka dia cacat atau terputus (HR. Ahmad, 8355).

Jika seorang ilmuwan telah selesai melakukan, sebut saja menyiapkan draf pengembangan idea akademis, sebelum dipublikasikan dalam komunitas atau kolega saintisnya, ia dianjurkan menutup tulisannya dengan Wallâhu a'lamu bishawâb, selanjutnya diserahkan kepada Allah. Inilah yang dimaksud antara lain "waizâa 'azamta fatawakalta 'alallâh. Jadi, dalam semua langkah kegiatan ilmu, seorang ilmuwan muslim harus selalu berkesadaran ilahiyah, tidak bebas nilai di luar ilmu.

Ketika suatu asumsi atau postulat, paradigma, konsep, teori, ilmu, atau teknologi telah dihasilkan oleh sang pemikir (thinker), bertumpu pada ayat 191 dari surat Ali Imran, bahwa segala sesuatu ada manfaatnya dengan pola manfaat umum, termasuk anak kandungnya yaitu teknologi bisa dimanfaatkan kepada apek-aspek 
lain di luar ilmu yang bersangkutan, artinya juga dapat dimanfaatkan oleh ilmu lain. Dapat dicontohkan teori pendidikan stimulus-respon dari Thorndike, Watson, Hull, Guthrie, dan Skinner ${ }^{8}$. Teori ini lalu berkembang menjadi aliran psikologi belajar yang berpengaruh terhadap arah pengembangan teori dan praktik pendidikan dan pembelajaran yang dikenal sebagai aliran behavioristic ? Selanjutnya, teori itu dapat dimanfaatkan dalam ranah kegiatan dakwah bil ḥâl, umpama memberi santunan kepada objek dakwah untuk mengikuti suatu kegiatan majlis ta' lim, pengajian ahad pagi, subuh ceria, majlis zikir, bershalawat, mujahadah kubra, atau kegiatan ritual keagamaan lainnya. Biasanya, dakwah dengan modus seperti itu menarik lebih banyak masa dakwah dibanding dengan dakwah malaikatan. Dalam dakwah malaikatan biasanya hanya dihadiri oleh sedikit masa. Umumnya, mereka ini dimotifasi ingin belajar mencari ilmu atau bahasa yang hiperboliknya terobesesi mencari kebenaran, terutama dalam beribadah mahdlah.

\section{Aksiologi Ilmu Manajemen Pendidikan Islam}

Telah disebutkan bahwa ilmu manajemen pendidikan Islam berada pada bidang ilmu teknik atau ilmu praktis. Ilmu ini merupakan pengembangan dari ilmu pendidikan Islam. Ilmu pendidikan Islam merupakan pengembangan dari ilmu Islam, yaitu tafsir Alquran. Tafsir Alquran bersumber dari Naskah Alquran itu sendiri. Sumber lain Ilmu manajemen pendidikan Islam adalah pengembangan dari ilmu manajemen pendidikan. Ilmu manajemen pendidikan merupakan pengembangan dari ilmu manajemen. Ilmu manajemen merupakan pengembangan dari ilmu ekonomi. Ilmu ekonomi merupakan pengembangan dari ilmu sosial atau sosiologi ${ }^{10}$. Jadi, ilmu manajemen pendidikan Islam memiliki moyang dari Islam itu sendiri maupun dari ilmu Barat, yaitu filsafat yang sekularistik.

Nally, 1979).

${ }^{8}$ N.L Gege dan D Berliner, Educational Psychology, Second (Chicago: Rand Mc.

${ }^{9}$ Saefullah, Manajemen Pendidikan Islam.

10 Bahrul Ulum dan Mufarrohah, "Kontribusi Ibnu Khaldun Terhadap Perkembangan Ekonomi Islam Pendahuluan," IQTISHODIA Jurnal Ekonomi Syariah 1, no. 2 (2016): 17-33. 
Ketika suatu cabang ilmu terdapat nama Islam, tentu nilai manfaatnya bukan sekedar pada ilmu itu sendiri, melainkan secara penuh adalah untuk beribadah kepada Allah karena realitas hidup ini hanyalah untuk beribadah kepada-Nya (QS at-Taubah/9:31; alBayyinah/98:5; az-Zâriyât/51:52; an-Nûr/22:55). Akan tetapi, kalau hanya disebutkan bahwa nilai ilmu manajemen pendidikan Islam untuk mengabdi kepada Allah tentu sama saja sebanding dengan mengatakan bahwa jumlah bintang di langit lebih dari dua. Pernyataan ini memang benar, tetapi terandai bahwa kebenaran itu bergraduasi, mulai dari yang sangat longgar hingga yang paling akurat dan spesifik. Allah sendiri mengajarkan tentang graduasi pengetahuan mulai dari 'ilmul yaqín hingga 'ainul yaqín (QS. atTakâŝur/102: 5-7). Dapat dirumuskan di sini bahwa nilai manfaat ilmu manajemen pendidikan Islam adalah efektifitas dan efisiensi hal-hal yang terkait dengan manajemen pendidikan Islam, mencakup berbagai unsur dimensi kelembagaan maupun dimensi program studi. Dasar, perencanaan, pelaksanaan, maupun evaluasi ilmu ini adalah Islam ${ }^{11}$. Ciri manajemen Pendidikan Islam mencakup: (1) secara umum sesuai dengan syariat, (2) diniatkan sebagai ibadah yang secara teknis untuk menjaga agama, jiwa, akal, keturunan, dan harta agar berfungsi sebagaimana mestinya, (3) adil dalam melaksanakan kepengelolaannya ketika ber-mu'âsyarah diantara sesama manusia, dan (4) para pelaku kepengelolaan, terutama top leader dan manajer harus amanah ${ }^{12}$. Tambahan ciri lain disebutkan bahwa hubungan antara atasan kepada bawahan atau sebaliknya merupakan hubungan persaudaraan umat ${ }^{13}$.

Secara subjektif, UIN Walisongo mengembangkan "the unity of sciencies" atau istilah dalam bahasa Arab 'Waḥdatul 'Ulûm, dengan paradigma:

1. Integrasi, bahwa berbagai cabang ilmu satu dengan yang lainnya saling berhubungan, bersumber dari ayat-ayat Allah, baik yang diperoleh dari Nabi, eksplorasi akal, maupun eksplorasi terhadap alam.

11 Sudarwan Danim dan Suparno, Manajemen dan Kepemimpinan Transformasional Kekepalasekolahan (Jakarta: Rineka Cipta, 2009).

${ }^{12}$ Fahrurrozi, Manajemen Pendidikan Islam (Semarang: Karya Abadi Jaya, 2015).

${ }^{13}$ Saefullah, Manajemen Pendidikan Islam. 
2. Kolaborasi, memadukan nilai universal Islam dengan ilmu pengetahuan modern untuk memperoleh kualitas hidup yang lebih baik di era moderen ini.

3. Dialektika, mendialogkan dengan intens antara ilmu yang bersumber dari wahyu, ilmu moderen, dan kearifan lokal.

4. Prospektif, berharap besar bahwa proyek unity of science akan menghasilkan profil ilmu baru yang berkarakter humanitis, etis, bermartabat untuk kelestarian alam

5. Pluralistik, bahwa unity of science mengakui ada realitas pluralistik dalam dunia ilmu inklusif metodenya masing-masing. ${ }^{14}$

Selanjutnya, secara lebih teknis, penjelasan unity of sciencies diilustrasikan bagaikan intan yang bersinar ke dalam berbagai penjuru. Sumbu sinar itu adalah Allah yang telah menjelma menjadi kalam-Nya yaitu Alquran termasuk di dalamnya hadis maqbûl, selanjutnya sinar yang memancar mengkristal menjadi agama dan humaniora, pancaran sinar selanjutnya adalah sains alam, sains sosial, matematika dan sains computer, profesi dan sains terapan, dan terakhir ilmu-ilmu baru 15. Ilmu manajemen pendidikan Islam dan filsafat manajemen pendidikan Islam tentu merupakan salah satu yang terkandung dalam ilmu baru yang wujudnya sekarang adalah program studi baik level strata satu (sarjana), strata dua (magister), maupun strata tiga (doctor).

Karena seluruh pengembangan bidang studi pada UIN Walisongo didasarkan pada visi, misi, dan tujuan, maka secara sistematis pula, nilai manfaat dari ilmu dan filsafat manajemen pendidikan Islam bersinergi dengan visi, misi, dan tujuan UIN Walisongo pula. Adapun visi, misi, dan tujuan UIN Walisongo adalah sebagai berikut:

Visi UIN:

Universitas Islam Riset Terdepan Berbasis pada Kesatuan Ilmu Pengetahuan untuk Kemanusiaan dan Peradaban.

Misi UIN

${ }^{14}$ Muhyar Fanani, Paradigma Kesatuan Ilmu(Semarang: Universitas Islam Negeri, ${ }^{15}$ Fanani. 
1. Menyelenggarakan pendidikan dan pengajaran IPTEKS berbasis kesatuan ilmu pengetahuan untuk menghasilkan lulusan profesional dan berakhlak al-karimah;

2. Meningkatkan kualitas penelitian untuk kepentingan Islam, ilmu dan masyarakat;

3. Menyelenggarakan pengabdian yang bermanfaat untuk pengembangan masyarakat;

4. Menggali, mengembangkan, dan menerapkan nilai-nilai kearifan lokal;

5. Mengembangkan kerjasama dengan berbagai lembaga dalam skala regional, nasional, dan internasional;

6. Mewujudkan tata pengelolaan kelembagaan profesional berstandar internasional. ${ }^{16}$

Tujuan

1. Melahirkan lulusan yang memiliki kapasitas akademik dan profesional dengan keluhuran budi yang mampu menerapkan dan mengembangkan kesatuan ilmu pengetahuan;

2. Mengembangkan riset dan pengabdian kepada masyarakat yang kontributif bagi peningkatan kualitas kehidupan masyarakat dalam beragama, berbangsa, dan bernegara.

Menurut ${ }^{17}$, melalui cara berpikir rasional dan koherensial sebagai unsur berpikir kefilsafatan dari kulliyah (universalia) kepada juziyyah (partikularia) Visi, misi, dan tujuan UIN Walisongo, di-break down yang lebih mikro ke dalam struktur keilmuan yang salah satunya menjadi visi, misi, dan tujuan fakultas Ilmu Tarbiyah dan Keguruan. Adapun visi, misi, dan tujuan dari Fakultas ilmu tarbiyah dan keguruan adalah sebagai berikut:

Visi

Model Pendidikan Islam Unggul Berbasis Kesatuan Ilmu di ASEAN Tahun 2030

${ }^{16}$ Zuhriva Ulfi Ernadila, Tasya Putri Hendrika, dan Ahmad Fauzan Hidayatullah, "Implementasi Unity of Science terhadap Visi dan Misi UIN Walisongo Semarang," Jurnal Intelektualita: Keislaman, Sosial dan Sains 10, no. 1 (2021): 7-13, https://doi.org/10.19109/intelektualita.v10i1.7139.

${ }^{17}$ Munstansir \& Munir (2010) 
Misi

1. Menyelenggarakan pendidikan dan pembelajaran bidang pendidikan berbasis kesatuan ilmu untuk menghasilkan lulusan yang profesional dan berakhlak mulia;

2. Meningkatkan kualitas riset bidang pendidikan untuk kepentingan Islam, ilmu dan masyarakat;

3. Menyelenggarakan pengabdian bidang pendidikan yang bermanfaat untuk mengembangkan masyarakat;

4. Menggali, mengembangkan dan menerapkan nilai-nilai kearifan lokal dalam bidang pendidikan;

5. Mewujudkan tatakelola kelembagaan pendidikan yang profesional dan berstandar nasional;

6. Mengembangkan kerjasama bidang pendidikan dengan berbagai lembaga regional, nasional dan internasional.

Tujuan

1. Menghasilkan lulusan bidang pendidikan yang memiliki kompetensi akademik dan profesional dengan kemuliaan akhlak yang mampu menerapkan dan mengembangkan kesatuan ilmu;

2. Menghasilkan riset dan karya pengabdian kepada masyarakat bidang pendidikan yang kontributif untuk meningkatkan kualitas kehidupan masyarakat dalam beragama, berbangsa dan bernegara.

Dengan tetap konsisten berpikir kefilsafatan, visi, misi, dan tujuan penyelenggaraan fakultas Ilmu Tarbiyah dan Keguruan dibreak down ke dalam program studi manajemen pendidikan Islam sebagai berikut:

Visi

Model Manajemen Pendidikan Islam Unggul Berbasis Kesatuan Ilmu Tingkat Nasional Tahun 2027

Misi

1. Menyelenggarakan pendidikan dan pembelajaran di bidang manajemen pendidikan berbasis kesatuan ilmu dan berwawasan kearifan lokal untuk menghasilkan lulusan yang kompeten dan berakhlak mulia; 
2. Menyelenggarakan riset dalam bidang manajemen pendidikan berbasis kesatuan ilmu;

3. Menyelenggarakan pengabdian bidang manajemen pendidikan yang bermanfaat untuk mengembangkan masyarakat;

4. Mewujudkan tatakelola kelembagaan pendidikan yang profesional dan berstandar nasional;

5. Mengembangkan kerjasama bidang manajemen pendidikan dengan berbagai lembaga regional, nasional dan internasional. Tujuan

1. Menghasilkan lulusan bidang manajemen pendidikan yang memiliki kompetensi akademik dan profesional dengan kemuliaan akhlak yang mampu menerapkan dan mengembangkan kesatuan ilmu;

2. Menghasilkan riset dan karya pengabdian kepada masyarakat bidang manajemen pendidikan yang kontributif untuk meningkatkan kualitas kehidupan masyarakat dalam beragama, berbangsa dan bernegara.

3. Mewujudkan tatakelola jurusan MPI yang profesional dan berstandar nasional dan Mengembangkan kerjasama bidang manajemen pendidikan dengan berbagai lembaga regional, nasional dan internasional.

Dengan memperhatikan tujuan penyelenggaraan program studi manajemen pendidikan Islam, maka manfaat ilmu maupun filsafat manajemen pendidikan Islam adalah:

1. Manfaat praktis, yaitu manfaat di luar disiplin ilmu, mencakup:

a. Menghasilkan sarjana di bidang ilmu manajemen pendidikan Islam

b. Menghasilkan sarjana bidang ilmu manajemen pendidikan Islam yang berakhlak mulia

c. Menghasilkan sarjana yang mampu berkontribusi mengembangkan kehidupan masyarakat dalam beragama Islam

d. Menghasilkan sarjana yang mampu berkontribusi mengembangkan kehidupan dalam berbangsa, sebagai bangsa Indonesia 
e. Menghasilkan sarjana yang mampu berkontribusi mengembangkan kehidupan bernegara, yaitu dalam bingkai Negara Kesatuan Republik Indonesia

f. Terwujudnya tatakelola jurusan MPI yang profesional dan berstandar nasional

g. Pengembangan kerjasama bidang manajemen pendidikan dengan berbagai lembaga yang bertaraf regional, nasional, maupun internasional

2. Manfaat filosofis-teoritis, yaitu manfaat dari filsafat dan ilmu manajemen pendidikan Islam mencakup:

a. Riset keilmuan di bidang filsafat dan ilmu manajemen pendidikan Islam

b. Gagasan-gagasan pengembangan filsafat dan ilmu manajemen pendidikan Islam.

Dengan memperhatikan manfaat praktis maupun teoritis sebagaimana dijelaskan di atas dapat dinyatakan bahwa UIN Walisongo Semarang sejak dari level universitas hingga mengerucut pada program studi memilih paham gabungan antara the science for the science, dan the science for the others. Paham pertama mewujud dalam bentuk pengembangan akademis yang terus menerus secara objektif dan mandiri sesuai dengan kaidah ilmu yang makin lama tampak sosok keilmuan (the body of science) berbeda secara tajam dengan sosok ilmu yang lainnya, meskipun sangat berdekatan dan dalam satu rumpun keilmuan umpama ilmu Pendidikan Islam dengan ilmu manajemen Pendidikan Islam. Paham kedua mewujud dalam filsafat maupun ilmu berasal dan bermuara kepada wahyu ${ }^{18}$. Dalam hal ini Alquran, hadis, maupun hasil ijtihat ulama sebagai basis idea dalam semua langkah keilmuan, maupun misi ilmu itu sendiri, yaitu untuk peneguhan peradaban, kemanusiaan, dan revitalisasi local wisdom sejauh sinergi dengan spirit wahyu.

\section{Penutup}

Ontologi ilmu manajemen Pendidikan Islam bersifat empirik dan legal. Empirisitas ilmu ini melembaga dalam bentuk program studi manajemen Pendidikan Islam dengan dasar hukum antara lain PMA

\footnotetext{
${ }^{18}$ Fanani, Paradigma Kesatuan Ilmu.
} 
nomor 10 tahun 2010 sebagai bagian dari FITK UIN Walisongo Semarang. FITK merupakan satu fakultas sebagai bagian dari UIN Walisongo Semarang.

Dengan kerangka epistemologi unity of science, posisi ilmu manajemen Pendidikan Islam dapat dirunut melalui dua alur pemikiran. Alur pertama bersumber dari filsafat sebagai induk ilmu. Filsafat melahirkan antropologi kefilsafatan. Antrolopolgi kefilsafatan melahirkan antropologi ilmu. Antropologi ilmu melahirkan sosiologi. Sosiologi melahirkan ilmu ekonomi. Ilmu ekonomi melahirkan ilmu manajemen. Ilmu manajemen melahirkan ilmu manajemen Pendidikan. Ilmu manajemen berkembang melahirkan ilmu manajemen Pendidikan Islam, terkandung di dalamnya aksiologi ilmu manajemen Pendidikan Islam. Alur pemikiran kedua bersumber dari Alquran, as-sunnah, dan ijtihad ulama. Dari ketiga sumber ini lahirlah tafsir tematik tentang kependidikan Islam. Dari tafsir tematik ini lahirlah ilmu Pendidikan Islam. Dari ilmu Pendidikan Islam berkembang menjadi ilmu manajemen Pendidikan Islam. Dari ilmu Pendidikan Islam lahirlah ilmu manajemen Pendidikan Islam, terkandung di dalamnya aksiologi Manajemen Pendidikan Islam.

Aksiologi ilmu manajemen Pendidikan Islam bersifat teoritis dan praktis. Dimensi teoritis adalah pengebangan ilmu yang mandiri dari ilmu-ilmu lain di lingkungan UIN Walisongo sehingga secaa tajam dibedakan dengan ilmu-ilmu lain meskipun dalam satu rumpun keilmuan. Sementara itu, dimensi praktis memproduk kesarjanaan baik strata satu, strata dua, maupun strata tiga (paripurna) dengan profil saintis yang ulama atau ulama yang saintis.

Wallāhu A' lamu bi ash-Shawâb.

\section{DAFTAR PUSTAKA}

al-Qur' ân al-Karím.

Lidwa Pustaka-i-Software: Kitab Hadis 9 Imam, 2009.

Danim, Sudarwan, dan Suparno. Manajemen dan Kepemimpinan

Transformasional Kekepalasekolahan. Jakarta: Rineka Cipta, 2009.

Ernadila, Zuhriva Ulfi, Tasya Putri Hendrika, dan Ahmad Fauzan

Hidayatullah. "Implementasi Unity of Science terhadap Visi dan Misi UIN Walisongo Semarang." Jurnal Intelektualita: Keislaman, Sosial dan Sains 10, no. 1 (2021): 7-13. 
https://doi.org/10.19109/intelektualita.v10i1.7139.

Fahrurrozi. Manajemen Pendidikan Islam. Semarang: Karya Abadi Jaya, 2015.

Fanani, Muhyar. Paradigma Kesatuan Ilmu. Semarang: Universitas Islam Negeri, 2015.

Gege, N.L, dan D Berliner. Educational Psychology. Second. Chicago: Rand Mc. Nally, 1979.

Hamdani. Filsafat Sains. Bandung: Pustaka Setia, 2011.

Munstansir, Rizal, dan Misnal Munir. Filsafat Ilmu. Yogyakarta: Pustaka Pelajar, 2010.

Runes, De Dagobert. Dictionary of Philosophy. New Jersey: Littlefield Adams Co, 1976.

Saebani, Ahmad Beni, dan Koko Komarudin. Filsafat Manajemen

Pendidikan. Bandung: Pustaka Setia, 2016.

Saefullah. Manajemen Pendidikan Islam. Bandung: Pustaka Setia, 2019.

Sumedi, Agus. "Peranan Plasmafaresis pada Keracunan Bisa Ular Type

Neurotoksik: Studi Kasus di RSCM Jakarta." Penelitian Keperawatan

Medik 1, no. 1 (2018): 41-51.

Syarif, MM. Iqbal Tentang Tuhan dan Keindahan. Bandung: Mizan, 1984.

Ulum, Bahrul, dan Mufarrohah. "Kontribusi Ibnu Khaldun Terhadap

Perkembangan Ekonomi Islam Pendahuluan." IQTISHODIA Jurnal

Ekonomi Syariah 1, no. 2 (2016): 17-33.

"Jamhuriyyah Mishr 'Arabiyyah", 1979, al-Mu' jam al-Falsafy. al-Haiatul

'Ammah Lisyuūni, al-Qaharah: asy-Syabi' il Amiriyyah. 